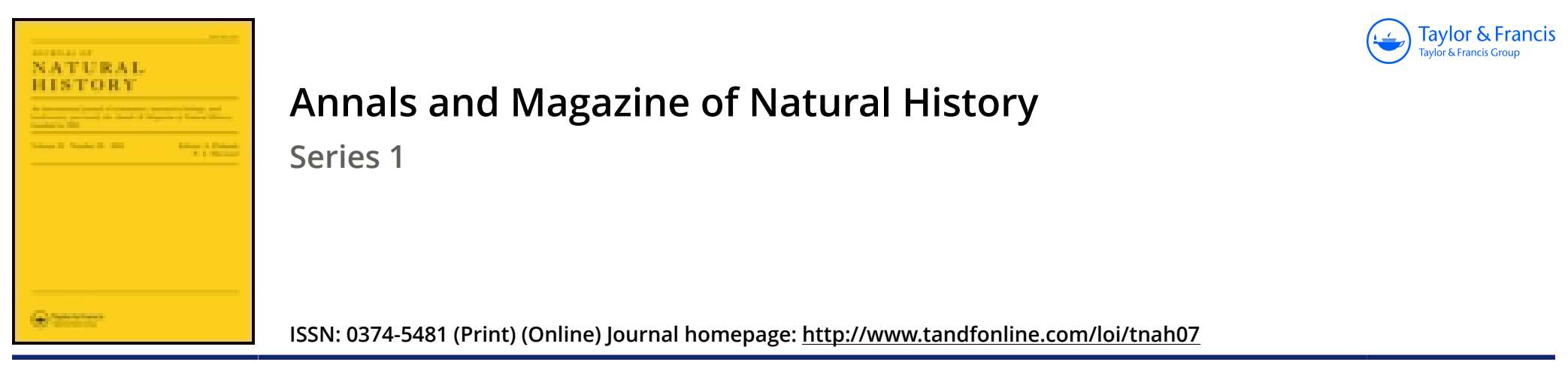

\title{
On mounting minute algæ for the microscope
}

\section{M.J. Berkeley}

To cite this article: M.J. Berkeley (1845) On mounting minute algæ for the microscope, Annals and Magazine of Natural History, 16:106, 351-352, DOI: 10.1080/037454809496536

To link to this article: http://dx.doi.org/10.1080/037454809496536

$$
\text { 曲 Published online: } 23 \text { Dec } 2009 .
$$

Submit your article to this journal ๔

Џll Article views: 2

Q View related articles $\asymp$ 
OCCUBRENCE OF AQUILA NAVIA IN IRELAND.

To Richard Taylor.

Clanmel, Oct. 7, 1845.

Dear Frrend,-At the request of my friend William Thompson of Belfast, I write to inform thee of the occurrence in the south of Ireland of an eagle new to these countries, Aquila navia (Linn.). I need enter into no description of the bird, as of course it is well-described in works on continental ornithology, but will just remark, that it is in the immature or spotted stage of plumage ; in contour it closely resembles the golden eagle, but is much smaller.

This specimen (which is now in my possession on loan) was shot on the estate of the Earl of Shannon, and was in a fallow-field in the act of devouring a rabbit at the time; this was in lst month (Jan.) 1845 ; and another said to be similarly marked, but of rather a lighter colour, is stated to have been shot in the same place a few days before: both had been observed in the neighbourhood (between Castlemartyr and Clay Castle near Youghal, co. Cork) for several weeks previous, sweeping over the low grounds there.

It at present belongs to my friend Samuel Moss of Youghal, who had it from the gamekeeper who killed it, but I think it is probable that before long it will be placed in the Museum of Trinity College, Dublin.

I have made a rough coloured drawing of it which $I$ sent to $\mathrm{Wm}$. Yarrell *, with similar information to what this note contains.

$$
\begin{aligned}
& \text { I am, thy friend, } \\
& \text { RoBerT Darrs, Jun. }
\end{aligned}
$$

ON MOUNTING MINUTE ALGA FOR THE MICROSCOPE.

In describing the method pursued by Mr. Thwaites in the preparation of algz for microscopical observation, $I$ stated that the cells were made of gold-size. As this is however liable to be softened and redissolved by the gold-size employed in fastening down the piece of thin glass, he found it advisable to look out for some more convenient substance.

He now uses two compositions, one suitable for very shallow, and the other for somewhat deeper cells. For the former he takes equal measures of finely-powdered lamp-black and litbarge; a portion of this is rubbed down with equal parts of gold-size and black japan, and the cells immediately formed on the glass slides with a camel's hair pencil. As the composition hardens very rapidly, the cells should be made as quick as possible, and to save time and trouble, a good many should be made at once. If the mixture becomes too thick for use before all the intended cells have been made, a little more gold-size may be rubbed down with it, and this may be repeated if necessary, but the last-made cells will take longer drying than the first. Before the walls are quite hard, they may be flattened by pressing them with a piece of wet glass. If this is not done, it takes

* For insertion in his 2nd edition of ' British Birds, ${ }^{2}$ expected to appear next month. 
a longer time to grind down the irregularities of the surface, which is best effected by rubbing them upon a piece of wet unpolished marble.

For the deeper cells Mr. Thwaites finds nothing so good as marine glue, which must be melted and dropped on the slip of glass, like sealing-wax, then warmed and flattened with a piece of wet glass : what is superfluous must be cut away with a knife, so as to leave only the wall of the cell; should this become loose, it ean easily be fixed by heating the other side of the slip of glass over a spirit-lamp and gently pressing. Before these cells are used, it is desirable to flatten them by rubbing gently upon a piece of wood and then upon the wet marble.

In using the cells, as small a quantity as possible of gold-size, of a thick consistence, should be laid on the wall of the cell, and also on the edge of the piece of thin glass ; and in covering up the cells, gentle pressure should be employed in order to squeeze out the superfluous fluid.

It would be a very useful thing for travellers to take with them the proper ingredients for preparing the two solutions for fresh and marine algæ. A portion of each species of alga might then be preserved in small phials carefully sealed and ticketed, which may be mounted and observed at leisure. The benefit of such a practice has been strongly impressed upon me during the examination of some highly curious foreign algæe which have lost many of their distinctive characters in drying.

\section{On the Discovery of a Fossil Frog and Butlerfly in the Gypsum Deposits of Aix. By M. Coquand.}

Among the fossils in my possession from the gypsum formation of Aix, a remarkable and very distinct impression of a reptile belonging to the order of the Batracians, and to the family Anource, has particularly caught my attention: M. Boué (Guide du Géol. vol. ii. p. 259) notices indeed, in the tertiary formations, the presence of some reptiles, such as salamanders, frogs and ophidians; but as he does not enter into any details, either of their description or the localities in which they have been found, the palrontologist will perhaps read with interest some details respecting the species in my possession. Its dimensions are as follows :-

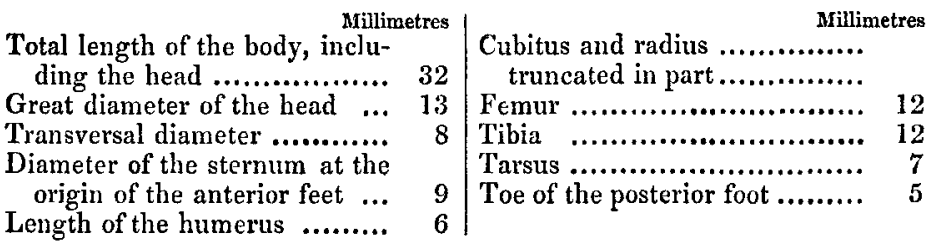

The body of this species, which I shall name Rana aquensis, is not so plump as that of the common frog; its head, although as flat, is more elongated, and is terminated by a snout which describes an al- 